\section{Drugs used in the treatment of oral mucosal diseases}

\section{Oral mukoza hastalıklarının tedavisinde kullanılan ilaçlar}

\section{Dr. Gökay Karapınar}

İstanbul University, Faculty of Dentistry,

Department of Oral and Maxillofacial Surgery, İstanbul Orcid ID: 0000-0002-7531-4237

\section{Prof. Meral Ünür}

İstanbul University, Faculty of Dentistry,

Department of Oral and Maxillofacial Surgery, İstanbul

Orcid ID: 0000-0003-4510-1668

Received: 7 August 2018

Accepted: 28 January 2019

doi: 10.5505/yeditepe.2019.96158

\section{SUMMARY}

The oral mucosa and the surrounding tissues are the entrance to the body, where oral mucosa-specific lesions can be seen, and where symptoms or signs of many systemic diseases can be observed. The etiology of the lesions occurring in the oral mucosa may be trauma, infection, immunological causes or idiopathic. Drug application onto the mucosa covering the oral cavity has long been a field of pharmacology. Lesions that occur as a symptom of systemic diseases are usually seen as ulcerations. The purpose of the treatment is to apply symptomatic treatments that mainly improve the patient's comfort while solving the underlying problem. These are achieved primarily by correcting oral hygiene, regulating the diet, and prescribing medicines in the appropriate manner mentioned in the article. In this review, we aimed to review the drugs used in oral mucosal diseases by the dentists who frequently deal with them.

Keywords: Oral mucosa, drugs, oral ulceration, oral mucosal lesions

\section{ÖZET}

Oral mukoza ve çevre dokular çok sayıda sistemik hastalığın belirtilerinin görülebildiği bir bölge olduğu gibi sadece oral mukozaya özgü lezyonların meydana geldiği, vücudun giriş kapısıdır. Ağız mukozasında görülen lezyonların etkeni travma, enfeksiyon, immünolojik ve idiyopatik nedenler olabilir. Oral kaviteyi örten mukoza üzerinde ilaç uygulaması eskiden beri farmakolojinin uğraşı alanı olmuştur. Sistemik hastalıkların belirtisi olarak meydana gelen lezyonlar genelde ülserasyonlar şeklinde görülmektedir. Tedavide hedef, esas olarak altta yatan sebebi çözmekle beraber hasta konforunu arttıran semptomatik tedaviler uygulamaktır. Bunlar başta ağız hijyenini düzeltmek, diyeti düzenlemekle birlikte yazıda belirtilen ilaçların uygun bir şekilde reçete edilmesiyle sağlanır. Bu derlemede oral mukozal hastalıklarla sıklıkla karşılaşan diş hekimlerinin, tedavide uygulamaları gereken ilaçlar hakkında detayı bilgi verilmesi amaçlanmıştır.

Anahtar kelimeler: Oral mukoza, ilaçlar, oral ülserasyon, oral mukozal lezyonlar

\section{INTRODUCTION}

The oral mucosa and the surrounding tissues are the entrance to the body, where oral mucosa-specific lesions can be seen, and where symptoms or signs of many systemic diseases can be observed. The etiology of the lesions occurring in the oral mucosa may be trauma, infection, immunological causes or idiopathic. Drug application onto the mucosa covering the oral cavity has long been a field of pharmacology. However, few forms of drugs have desired properties on the oral mucosa.

In this review, we aimed to review the drugs used in oral mucosal diseases by the dentists who frequently deal

\footnotetext{
Corresponding author:

Dr. Gökay Karapınar

Istanbul University, Faculty of Dentistry,

Department of Oral and Maxillofacial

Surgery Fatih/Istanbul

Phone:05385914435

E-mail: gokaykarapinar@gmail.com
} 
with them.

\section{Factors Affecting Wound Healing}

A wound is the deterioration of the integrity of tissue covering the body by a physical damage. This is a physiological process that occurs by many cells and the products of these cells come together. Wound healing is a complex process affected by mechanical, biological, local and systemic factors. It mainly consists of three phases: inflammation, proliferation and maturation. ${ }^{1}$

1) Inflammation phase

Hemostasis and inflammatory infiltration occur in the inflammatory phase. Blood vessels are disrupted at the site of tissue injury and platelets initiate hemostasis by forming a cellular plaque in the wound region. Collagen and microfibrils in the subendothelium are exposed to the circulation in the wound area, which activates thrombocytes and causes platelet adhesion. Arachidonic acid metabolites, proteases and various growth factors released from platelets adhered to the subendothelium contribute to the formation of the inflammatory process. Inflammation, increased vascular permeability and activation of the complement system result in migration of various immunological cells, primarily neutrophils, to the wound area. These immunological cells secrete proteolytic enzymes and cytokines, while on the other side, they start to release free radicals and play a protective role against foreign organisms. At the end of this phase, the number of immunological cells begins to decrease; then, endothelial cells and fibroblasts appear in the wound area and initiate the proliferative phase..$^{2-4}$

2) Proliferation phase

Fibroplasia, granulation formation, angiogenesis, contraction and epithelization occur in the proliferative phase: the proliferative phase is characterized by angiogenesis, collagen production and storage, and wound contraction. In angiogenesis, new blood vessels are formed from the epithelial cells to provide nutrients and oxygen for the proliferating cells. During epithelization, the epithelial cells proliferate and spread to the wound region. On the other hand, fibroblasts proliferate at the wound site and transform into myofibroblasts. They secrete collagen and fibronectin, which are involved in the new connective tissue to form transient extracellular matrix. Collagen is an important component that supports the extracellular tissue and contains large amounts of hydroxyproline. Contraction of the scar tissue occurs by the contraction of myofibroblasts. In the early period of wound healing, keratinocytes appear and initiate re-epithelization. Thus, newly formed granulation tissue begins to replace the missing tissue. ${ }^{2,3}$

3) Maturation phase

Scar tissue forms in the maturation phase and wound healing is completed. The remodeling phase begins when the keratinocytes differentiate into dermis. The most important feature of this phase, which starts after formation of the cellular matrix, is accumulation of collagen in the wound. Collagen synthesis is then initiated with the contribution of glycosaminoglycan (GAG) and proteoglycans. As a result of cross-linking of collagen fibrils that are in the form of fine yarns (filaments), their thickness gradually increases. ${ }^{2,3}$

Factors affecting wound healing include: ${ }^{5}$

1) Bacterial, viral and fungal infections

2) Medications used

3) Diabetes mellitus

4) Nutrition

5) Age

6) Environmental factors

\section{Drugs Used in the Treatment of Oral Mucosal Diseases}

1) Corticosteroids

Corticosteroids are extremely important drug groups due to their strong anti-inflammatory, anti-allergic and immunosuppressive effects. They inhibit pathways that play roles in the activation of the inflammatory responses such as migration of neutrophils and monocytes to the site of inflammation, antigen presentation by macrophages to lymphocytes, lymphocyte proliferation, activation and differentiation.

Corticosteroids have important effects on carbohydrate, protein and lipid metabolism as well as anti-inflammatory effects, effects on the hematopoietic, nervous and cardiovascular systems, bone and calcium metabolism, and endocrine functions such as inhibition of growth, and adrenal cortex atrophy. Therefore, these effects should be kept in mind while using these drugs. ${ }^{6,7}$

Routes of Corticosteroid Administration

1) Local: Adverse effects are less frequent in local treatment than in systemic treatment.

a) Topical: Applied over the skin and mucosa. Cream, gel and lotion forms are available. Systemic side effects are minimal. Adrenal axis suppression may rarely be seen due to systemic absorption.

b) Intraarticular: Intraarticular corticosteroid injections are mostly used to treat acute and chronic inflammatory conditions.

c) Nasal: It is usually used in the treatment of allergic rhinitis.

d) Inhalation: Beclomethasone dipropionate, budesonide, flunisolide, fluticasone propionate and mometasone furoate are corticosteroids that can be administered by inhalation.

e) Systemic route: Systemic treatment may be administered orally or intravenously. 
Oral Mucosal Diseases in which Corticosteroids Can be Used

1. Oral submucous fibrosis

2. Oral lichen planus

3. Mucous membrane pemphigoids

4. Erythema multiforme

5. Mucocele

6. Bullous pemphigoid

7. Recurrent aphthous stomatitis

8. Pemphigus Vulgaris and Mucous Membrane Pemphi goid

9. Behçet's Syndrome

10. Stevens-Johnson Syndrome (SJS)

11. Keloid and hypertrophic scars

12. Graft Versus Host Disease

13. Systemic Lupus Erythematosus (SLE)

14. Allergic diseases in the maxillofacial region

Side Effects of Corticosteroids 8,9

1) Osteoporosis-Osteonecrosis

2) Suppression of growth

3) latrogenic Cushing syndrome

4) Myopathy

5) Psychiatric side effects

6) Susceptibility to infection development

7) Peptic ulcer

8) Oral moniliasis, hoarseness

9) Delayed wound healing, skin atrophy

10) Insulin resistance- Diabetes mellitus development

11) Cataract, glaucoma development

12) Adrenal insufficiency

13) Edema and hypokalemia

14) Hypercalciuria

\section{a) Topical Corticosteroids}

Triamcinolone acetonide

Triamcinolone acetonide (TA) is a synthetic, long-acting (due to poor solubility) glucocorticoid widely used in the treatment of inflammatory diseases. The anti-inflammatory activity of TA is 5-times more potent than that of hydrocortisone. ${ }^{10,11}$ It is difficult to use for the oral mucosa in pharmacological forms such as ointment, cream, solution, or lotion due to saliva, temperature, muscle movements, tongue and swallowing. For this reason, adhesive forms have been launched to provide adhesion onto the oral mucosa. (It is available as 'Kenacort-A Orabase', which is frequently used in our country)

Clobetasol propionate

Clobetasol proprionate is a potent corticosteroid. Its gargle and ointment forms are frequently used. The gargle form is the preferred form, because it can easily reach every point in the oral cavity, whereas the ointment form is affected by oral motions and cannot remain on the le- sions for a sufficient duration. In previous publications, it was stated that each application could be done for 3-5 minutes, 2 or 3 times a day, with the drug at a concentration range of $0.025 \%$ and $0.05 \% .{ }^{10,11}$

It is used for the treatment of persistent and multiple oral lesions that cause severe pain and difficulty in talking or swallowing. In some studies, an increase in the concentration of oral Candida albicans was observed with the use of clobetasol, and it was reported that in addition to clobetasol, that anti-fungal nystatin mouthwash could also be given to the patients. ${ }^{12}$

Fluocinonide

Fluosinonide is another highly potent corticosteroid used in dermatological and oral mucosal diseases. ${ }^{13} 0.1 \%$ Fluocinolone acetonide has been proven to be effective in the management of OLP. ${ }^{14}$

Hydrocortisone acetate

Halogen-free corticosteroids, such as hydrocortisone acetate, are useful for step-wise treatment (using potent steroids until acute syndromes are resolved, continuing with weaker steroids in the subacute phase, and ending the therapy with only lavage use after symptoms have subsided).

It is a natural glucocorticoid. It is well absorbed in case of systemic administration. It can be applied topically or by intramuscular injection. ${ }^{15}$ It has a weak potency and can be used in as a topical preparation in dentistry.

Dexamethasone

Dexamethasone is a glucocorticoid, which contains sodium polyacrylate with anti-inflammatory properties and is used topically to treat oral ulcers. Previous studies have shown that dexamethasone is good at binding to moist mucosal surfaces, preserving the wound and maintaining the effective drug concentration for a long time. Dexamethasone ointment has been shown to be effective and safe in the treatment of RAS. ${ }^{16}$ Na'mah et al. compared widely used triamcinolone acetonide with dexamethasone ointment and found that both were equally effective. ${ }^{16}$

b) Systemic corticosteroids

Considering the serious side effects of systemic corticosteroids, they may be used in the treatment of some persistent lesions in and around the mouth after consultation with the relevant specialist (internal medicine, dermatology, rheumatology, ophthalmology, etc). The use of systemic corticosteroids should be considered when the response to other topical treatments is unsatisfactory. Betamethasone, dexamethasone, hydrocortisone, methylprednisolone, prednisolone are the available systemic corticosteroid preparations. The most commonly used drug in this group is prednisone/prednisolone. It is very important to complete any course of systemic glucocorticosteroids, even at quite low dosages, with a gradual 
tapering-off to allow the adrenal cortex to recover from the negative feedback effect of the drug. There are several ways to manage this tapering-off effect. The main rule is that the greater the initial dosage and the longer the course of treatment, the longer and more gradual should be the tapering- off process. Doses should be lowered slowly. ${ }^{7}$

The side effects of short-term glucocorticosteroid prescribed for the treatment of mucosal diseases are spontaneously reversible, but those of long-term administration are more serious. Some subjects are at greater risk of the side effects as, for example those with liver disease who do not have the capacity to adequately metabolize the drug, and those with hypoalbuminemia who will have increased levels of free serum glucocorticosteroids. ${ }^{16}$

\section{2) Dexpanthenol (Epithelizing agent)}

Pantothenic acid was discovered in 1931 by Roger J. Williams. The richest sources of pantothenic acid are cereals and legumes. Dexpanthenol is a hygroscopic and viscous clear, odorless liquid or may have slightly characteristic odor. It is freely soluble in water, alcohol, methyl alcohol and propylene glycol; it can dissolve in chloroform and ether, while being slightly soluble in glycerol. Dexpanthenol is the alcohol form of pantothenic acid, which is a factor of the vitamin B complex. In addition, dexpanthenol is well absorbed from the skin compared to pantothenic acid. ${ }^{8}$

Pantothenic acid is part of the structure of the coenzyme A complex. Coenzyme A is involved in many metabolic reactions in the body in the form of acetyl-coenzyme $A$. The main metabolic reactions that involve coenzyme $A$ are carbohydrate metabolism, acetylcholine synthesis, cholesterol synthesis, lipid oxidation by oxidation, synthesis of adrenal cortex steroid hormones, and acetylation and biotransformation of drugs and other xenobiotics in the liver. Despite all of the previous studies, the mechanism of action of dexpanthenol is not fully explained. Dexpanthenol is administered orally, parenteral and topically. After absorption, the pantothelium transforms into enriched acid in the liver and is incorporated into endogenous vitamin deposits. When topically applied in the form of ointments, lotions, lozenges or other pharmaceutical forms, they are absorbed rapidly. Pantothenic acid is an essential molecule in the organism for the formation and renewal of skin and mucous membranes. ${ }^{9}$

Dexpanthenol facilitates epithelization by supporting fibroblast proliferation. Microarray analysis studies have shown that dexpanthenol improves wound healing by increasing the IL-6 and IL-8 expression. ${ }^{17}$
3) Topical Analgesic Agents and Mouthwashes

a) Mouthwashes

The goal of the antimicrobial mouthwashes frequently used in dental clinical practice is to reduce the number of microorganisms in the oral cavity. Chlorhexidine gluconate and benzydamine hydrochloride are the most commonly used active ingredients in antimicrobial mouthwashes.

The mouthwashes used in oral mucosal lesions are usually used in the treatment of gingivitis and periodontitis to reduce plaque-related bacteria proliferation, in the symptomatic treatment of ulceration, in the treatment of candida infections and in the prevention of pain resulting from oral inflammation.

Sodium fluoride containing mouthwashes are usually recommended for children with porosity in the tooth dentine and adults with a high risk of caries.

Chlorhexidine gluconate is a cationic bi-guanide with a broad antimicrobial spectrum. The durability of chlorhexidine is its main advantage among the mouthwashes. It tightly attaches to the surfaces in the oral cavity and maintains its effect with slow release. Chlorhexidine is available in $0.1 \%, 0.12 \%$ and $0.2 \%$ solutions. Chlorhexidine may cause color changes on the tongue and teeth in the mouth, but these effects disappear after cessation. ${ }^{18}$

Benzydamine hydrochloride $0.15 \%$ is a non-steroidal anti-inflammatory agent having different pharmacological profiles and pharmacokinetic properties compared to other group members. It is lipophilic and provides local anesthesia and has a stabilizing effect on all membranes. It is well absorbed after topical administration. Therefore, it has an analgesic effect in the acute inflammation that occurs in the soft tissue injury due to surgical and traumatic causes. It is mostly available in $0.15 \%$ solutions. $^{19}$ Listerine is a lipid-based phenol compound and is still frequently used today. The mechanism of action of Listerine results from bacterial cell wall destruction, bacterial enzymatic inhibition, and destruction of bacterial lipopolysaccharides and biofilm. ${ }^{19}$

Triclosan is a germicide composed of two phenols and one non-ionic atom. Its toxicity is minor and its antibacterial activity has a broad spectrum. It is added to toothpastes and used in mouthwashes. It has been reported that mouthwashes containing ethanol and zinc sulfate together with triclosan reduce the pain severity by $45 \%$ and prolong the ulcer-free period. ${ }^{20}$

Sodium lauryl sulphate (SLS) is a hydrophobic anionic agent with high affinity to protein molecules. There are mouthwash and paste forms available. It is not preferred due to harmful effects according to the results of studies conducted in recent years. ${ }^{21}$

Zinc salts are used due to their antibacterial properties. 
Furthermore, zinc salts reduce the acid rate in the plaque. Zinc ions have been found to reduce bacterial absorption and plaque build-up on teeth. ${ }^{21}$

Antifungal mouthwashes: The most important advantage of antifungal mouthwashes and topical agents is that their side effects and systemic toxicities are little or none compared to systemic agents. There are only nystatin-containing preparations available in our country in suspension form among mouthwashes with an antifungal property. After microbiological determination of Candida albicans, which causes oral candidiasis, it should be used in accordance with the doctor's recommendation. ${ }^{21}$ Lidocaine $\mathrm{HCl} 1 \%$ cream, lidocaine $2 \%$ gel or spray, mouthwashes containing benzocaine pastilles, benzocaine, and cetylpyridinium chloride are other effective topical agents in reducing pain. ${ }^{21,22}$

Tetracycline: Mouthwashes containing tetracycline reduce the size and duration of oral ulcers and pain. Tetracycline-containing mouthwashes have been demonstrated to be effective in prevention of secondary infections and concomitantly inhibit collagenase activity. ${ }^{23}$ Tetracycline group drugs exert their effect by local inhibition of collagenases and metalloproteinases and by inhibiting processes leading to inflammation, cell destruction and ulceration. Doxycycline applied in muco-adhesive gel format, has been reported to be more effective. ${ }^{22}$ It has been reported that minocycline $0.2 \%$-containing mouthwash more effectively decreases pain than that that containing tetracycline $0.25 \%$. 3\% diclofenac and $2.5 \%$ hyaluronic acid gel have been reported to be more effective in reducing pain compared to $3 \%$ lidocaine gel. ${ }^{23}$

Amlexanox is a drug that has been studied in recent years and has been found to be effective in the short-term particularly in the prodromal period. Its mechanism of action is not fully understood, but it is a topical agent with anti-inflammatory and anti-allergic effects. Amlexanox $5 \%$ paste or $2 \mathrm{mg}$ tablet was found to cause reduction in the number of aphthous ulcers and pain severity when used in the prodromal period. ${ }^{24}$

\section{4) Herbal Agents}

a) Centella asiatica extract (Gotu cola)

Cantella is obtained from the extract of the part of the plant called asiatica, which is outside the soil. This plant grows in Asia, Oceania, Africa and America. The active ingredients include triterpenic saponins such as amino acid, flavone, madecassic acid, acetic acid and asiaticoside. The re-epithelialization effect in the skin is thought to originate from the triperpenoid saponin in its content. This active substance enhances angiogenesis and collagen formation, and exerts an antioxidant effect in the wound region. Although only the ointment form is pres- ent in our country (Madecassol, Bayer Türk Kimya San. Ltd. Şti., İstanbul), also tablets, gels, creams and powders are available in other countries. The ointment form is recommended for skin lesions secondary to radiotherapy. ${ }^{25}$

\section{b) Aloe vera plant}

This is one of the oldest herbal agents known to positively affect wound healing. Aloe vera has been used for medical purposes in various cultures such as Greece, Egypt, Mexico, Japan and China for thousands of years. The botanical name of aloe vera is Aloe barbadensis miller, belongs to the family of Asphodelaceae (Liliaceae), and it is a woody, long-lived, meaty, pea-green colored plant. It is particularly grown in the Southwest Anatolia region in our country, the name of which is "sarısabır" or "ödağacı" in Turkish. Aloe vera contains 77 potentially active compounds including vitamins, enzymes, minerals, sugars, lignin, saponin, salicylic acid and amino acids. ${ }^{26}$ It binds to growth factor receptors in fibroblasts and increases their activity and proliferation. Aloe gel alters the amount of collagen, as well as the composition of collagen, leading to more type- 3 collagen and increased rate of collagen cross-linking. By this way, it accelerates the wound contraction and strengthens the scar tissue. After oral or topical application, it causes an increase in the synthesis of hyaluronic acid and dermatan sulfate in the granulation tissue during the wound healing process. ${ }^{27}$ In addition to the wound healing effects of aloe vera, it also has anti-inflammatory effects, laxative effects, antiviral and antitumor effects, moisturizing and anti-aging effects, and antiseptic effects, as well as reducing the harmful effects of ultraviolet and gamma rays on the skin. ${ }^{28}$ Studies conducted with humans and animals are insufficient according to the principles of 'evidence-based medicine'. The beneficial effects of Aloe vera have been reported in the treatment of seborrheic dermatitis, psoriasis, genital herpes, burns, type 2 diabetes, HIV infection, cancer prevention, wound healing, pressure ulcers, mucositis, radiation dermatitis, acne vulgaris, lichen planus, freezy, aphthous stomatitis and constipation. ${ }^{29}$ Studies have shown that aloe vera is not superior to corticosteroids, but that it may be used as a supportive agent. ${ }^{29}$ Although there are many clinical studies conducted with aloe vera, there is need for further evidence about the usefulness of this plant and the methods of its use.

\section{c) Triticum Vulgare extract (FITO cream)}

Triticum Vulgare extract supports wound healing and re-epithelization by stimulating mRNA and DNA synthesis in fibroblasts and lymphocytes. It enhances chemotaxis and fibroblast maturation by synthesizing collagen fibers and glycosaminoglycans. ${ }^{30}$

In the daily practice of medicine, this drug is particularly used in cases having skin changes and wounds sec- 
ondary to radiation, eczema and psoriasis-like symptoms, burns at every grade, persistent wounds, occupational skin disorders, cracks due to cold, and in cases where renewal of skin tissue slows or changes due to various reasons. ${ }^{30,31}$

\section{d) Chamomile}

Chamomile has been used as a herbal medication for ages. It contains various phytochemicals that provide therapeutic benefits. Mainly coumarins, flavonoids, essential oils and other substances are present in the composition of chamomile. It is used topically in skin and oral inflammation, wound healing. Chamomile is used in different conditions such as treating inflammation of the skin and mucous membranes, and for bacterial infections of the skin, oral cavity and gums. Among internal diseases, it is used in gastrointestinal disorders (spasm and inflammation). In addition, sedative, hypnotic, analgesic and immune-stimulant effects have been reported. ${ }^{32}$

Clinical trials have shown that chamomile is effective in mucositis secondary to radiotherapy and chemotherapy. ${ }^{33}$

\section{e) Clove oil (Eugenol)}

Eugenol is a substance obtained from cloves, which has local antiseptic, anesthetic, analgesic, and antiinflammatory properties and is frequently used in dentistry. Besides, it is used in the perfume and food industries. It has antiseptic (which inhibits bacterial replication), antifungal (against fungi), and antiviral effects (inhibits viral actions). ${ }^{34}$

\section{5) Other Systemic Drugs}

a) Dapsone (Dapsone; GlaxoSmithKline, India): It is an aniline derivative of the synthetic dapsone group. Its mechanism of action includes both antibacterial and anti-inflammatory effects. It inhibits neutrophil activation and chemotaxis. It reduces the number and size of oral and genital ulcers seen in Behçet's disease. The most common side effects are methemoglobinemia and hemolysis, but usually the drug is well tolerated. ${ }^{35}$

b) Thalidomide: Its use is very limited due to its teratogenicity and other side effects.

c) Sucralfate: Sucralfate is commonly used as an anti-acid in the treatment of stomach and duodenal ulcers. Its primary mechanism of action is forming a protective barrier over the ulcerated gastric mucosa region. It can be used local or systemic for the treatment of lesions in oral mucosa. Sucralfate suspension has been shown to provide rapid healing and pain reduction in oral and genital aphthous ulcers. ${ }^{36}$

d) Antimetabolites: Azathioprine and methotrexate have been shown to be beneficial in the treatment of orogenital aphthous ulcer in previous studies. 37 However, when the systemic side effects are taken into consideration, their use in the treatment of oral ulceration is very limited. ${ }^{37}$

e) Cyclosporin: Cyclosporins are powerful immunosuppressive drugs commonly used to prevent organ rejection after organ transplantation. This drug is used in the treatment of many diseases in which immunodeficiencies play a role in the etiology by suppressing $T$ cell mediated immunity. Side effects are more common than colchicine. These side effects include hirsutism, fever, fatigue and gastrointestinal symptoms. ${ }^{38}$

f) Interferon-a: Interferons are mainly considered as molecules regulating the immune system and are released in case of stress. It has antiviral, pro-apoptotic, anti-proliferative, and anti-angiogenic properties. They also regulate cell growth and differentiation. Serious side effects can be seen. ${ }^{39}$

g) Levamisole: Levamisole is an antihelminthic drug with a wide range of immunological effects both in-vivo and in-vitro. It has immunomodulatory property. Levamisole normalizes the CD4 / CD8 cell ratio by affecting the immune system, regulates T suppressor cell deficiency, and reduces the inflammatory response by altering the IL-6 and IL-8 levels. It has been reported that it can be used in the treatment of erythema multiforme, submucous fibrosis, pemphigus vulgaris, rheumatoid arthritis, various tumors and recurrent ulcers. ${ }^{40}$

h) Colchicine: Colchicine, an anti-inflammatory drug, has not found wide use because of its low therapeutic index and its potential for serious toxicity. Nevertheless, some studies have shown its benefit in the treatment of oral mucosal ulcers. ${ }^{41}$

\section{CONCLUSION}

Lesions seen in the oral mucosa may arise from a number of disorders, including idiopathic or immunological, as a sign of trauma, due to infection, local or systemic diseases. Lesions that occur as a symptom of systemic diseases are usually seen as ulcerations. The aim of the treatment is to apply symptomatic treatments that mainly improve the patient's comfort while solving the underlying problem. These are achieved primarily by correcting oral hygiene, regulating the diet, and prescribing medicines in the appropriate manner mentioned in the article. In addition, it is important that dentists, as the occupational group most frequently encountered with oral mucosal diseases, should keep their knowledge up-to-date about this topic.

\section{REFERENCES}

1. Şahin ÖK, Aksoy MÇ. Oral cerrahi işlemler sonrası yara iyileşmesine sigaranın etkileri. Atatürk Üniv Diş Hek Fak Derg 2014; 24: 3.

2. Aksoy $H$, Özakpınar, ÖB. Yara iyileşmesi ve oksidatif stres. Marmara Pharmaceutical Journal 2014;18:153 
158.

3. Ghosh K, Clark RA. Principles of tissue engineering. Editör: Lanza R, Langer R and Vacanti J. Wound Repair. II. Basic biology of wound repair, Elsevier Academic Press, 2007; 3rd Edition, p.1149-1161.

4. Sen CK, Roy S. Redox signals in wound healing. Biochim Biophys Acta 2008; 1780: 1348-1356.

5. Guo SA, DiPietro, LA. Factors affecting wound healing.L Dent Res 2010; 9: 219-229.

6. Gorski, J, Gannon, F. Current models of steroid hormone action: a critique. Annu Rev Physiol 1976; 38: 425450.

7. Rice JB, White AG, Scarpati LM, Wan G, Nelson WW. Long-term systemic corticosteroid exposure: a systematic literature review. Clin Ther 2017; 39: 2216-2229.

8. Poetker DM, Reh DD. A comprehensive review of the adverse effects of systemic corticosteroids. Otolaryngol Clin North Am 2010; 43:7 53-768.

9. Caplan A, Fett N, Rosenbach M, Werth, VP, Micheletti R. G. Prevention and management of glucocorticoid-induced side effects: a comprehensive review: a review of glucocorticoid pharmacology and bone health. J Am Acad Dermatol 2017; 76: 1-9.

10. Savage NW, McCullough, MJ.Topical corticosteroids in dental practice. Aust Dent J 2005;50: S40-S44.

11.Piñas L, García-García $A$, Pérez-Sayáns $M$, Suárez-Fernández $\mathrm{R}$, Alkhraisat $\mathrm{MH}$, Anitua $\mathrm{E}$. The use of topical corticosteroides in the treatment of oral lichen planus in Spain: A national survey. Med Oral Patol Oral Cir Bucal 2017; 22: e264-e269.

12. Gonzalez-Moles MA, Bravo M, Gonzalez-Ruiz L, Ramos P, Gil-Montoya JA. Outcomes of oral lichen planus and oral lichenoid lesions treated with topical corticosteroid. Oral Diseases 2018; 24: 573-579.

13. Lozada-Nur, F., Miranda, C., \& Maliksi, R. Double-blind clinical trial of $0.05 \%$ clobetasol proprionate ointment in orabase and $0.05 \%$ Fluocinonide ointment in orabase in the treatment of patients with oral vesiculoerosive diseases. Oral Surg Oral Med Oral Pathol and Oral Radiol 1994; 77: 598-604.

14. Thongprasom $K$, Luangjarmekorn $L$, Sererat $T$, Taweesap W. Relative efficacy of fluocinolone acetonide compared with triamcinolone acetonide in treatment of oral lichen planus. J Oral Pathol Med 1992; 21: 456-458.

15. Ceschel GC, Maffei P, Borgia SL, Ronchi C. Design and evaluation of buccal adhesive hydrocortisone acetate (HCA) tablets. Drug Delivery 2001; 8: 161-171.

16. Al-Na'mah ZM, Carson R, Thanoon IAJ. Dexamucobase: A novel treatment for oral aphthous ulceration. Quintessence Int 2009; 40: 399-404.

17. Kiran MS, Vidya S, Aswal GS, Kumar V, Rai V. Systemic and topical steroids in the management of oral mucosal lesions. J Pharm Bioallied Sci 2017; 9(Suppl 1): S1-S3.
18. Guallar IB, Soriano YJ, Lozano AC. Treatment of recurrent aphthous stomatitis. A literature review. J Clin Exp Dent 2014; 6: 168-174.

19. Roopashri G, Jayanthi K, Guruprasad R. Efficacy of benzydamine hydrochloride, chlorhexidine, and povidone iodine in the treatment of oral mucositis among patients undergoing radiotherapy in head and neck malignancies: A drug trail. Contemp Clin Dent. 2011; 2: 8-12. 20. Skaare AB, Herlofson BB, Barkvoll P. Mouthrinses containing triclosan reduce the incidence of recurrent aphthous ulcers (RAU). J Clin Periodontol 1996; 23: 778-781. 21. Rösing CK, Cavagni J, Gaio EJ, Muniz FWMG, Ranzan $\mathrm{N}$, Oballe HJR, et al. Efficacy of two mouthwashes with cetylpyridinium chloride: a controlled randomized clinical trial. Braz Oral Res 2017; 31: e47.

22. Lalla RV, Schubert MM, Bensadoun RJ, Keefe D. Anti-inflammatory agents in the management of alimentary mucositis. Support Care Cancer 2006; 14: 558-565.

23. Saxen MA, Ambrosius WT, Rehemtula al-KF, Russell AL, Eckert GJ. Sustained relief of oral aphthous ulcer pain from topical diclofenac in hyaluronan: a randomized, double-blind clinical trial. Oral Surg Oral Med Oral Pathol Oral Radiol Endod 1997; 84: 356-361.

24. Liu J, Zeng X, Chen Q, Cai Y, Chen F, Wang Y, et al. An evaluation on the efficacy and safety of amlexanox oral adhesive tablets in the treatment of recurrent minor aphthous ulceration in a Chinese cohort: a randomized, double-blind, vehicle-controlled, unparallel multicenter Clinical trial. Oral Surg Oral Med Oral Pathol Oral Radiol Endod 2006; 102: 475-481.

25. Bylka W, Znajdek-Awiżeń P, Studzińska-Sroka E, Dańczak-Pazdrowska A, Brzezińska M. Centella asiatica in dermatology: an overview. Phytother Res 2014; 28:1117-1124.

26. Ajose FO. Some Nigerian plants of dermatologic importance. Int J Dermatol 2007; 46 Suppl 1: 48-55.

27. Mantle D, Gok MA, Lennard TW. Adverse and beneficial effects of plant extracts on skin and skin disorders. Adverse Drug React Toxicol Rev 2001; 20: 89-103.

28. Feily A, Namazi MR. Aloe vera in dermatology: a brief review. G Ital Dermatol Venereol 2009;144:85-91.

29. Surjushe A, Vasani R, Saple DG. Aloe vera: a short review. Indian J Dermatol 2008; 53: 163-166.

30. Sanguigno L, Minale $M$, Vannini $E$, Arato $G$, Riccio $\mathrm{R}$, Casapullo A, et al. Oligosaccharidic fractions derived from Triticum vulgare extract accelerate tissutal repairing processes in in vitro and in vivo models of skin lesions. $J$ Ethnopharmacol 2015; 159: 198-208.

31. Carrasco-Chaumel E, Cardona AF, Ospina EG, Montaño LM, Noemí R, Bleda $M$, Castro $C$. Triticum vulgare mouthwashes (TVM) for patients (pts) with oral mucositis (OM) induced by chemotherapy and chemoradiotherapy (ONCOLGroup study). J Clin Oncol 2009; 27(15S): 
e20570-e20570.

32. Srivastava, JK, Shankar E, Gupta S. Chamomile: a herbal medicine of the past with a bright future. Mol Med Rep 2010; 3: 895-901.

33. Mazokopakis EE, Vrentzos GE, Papadakis JA, Babalis

DE, Ganotakis ES. Wild chamomile (Matricaria recutita L.) mouthwashes in methotrexate-induced oral mucositis. Phytomed 2005; 12: 25-27.

34. Mohammadi Nejad $S$, Özgüneş $H$, Başaran N. Pharmacological and Toxicological Properties of Eugenol. Turk J Pharm Sci 2017; 14: 201-206.

35. Sharquie KE, Najim RA, Abu-Raghif AR. Dapsone in Behçet's disease: a double-blind, placebo-controlled, cross-over study. J Dermatol 2002; 29: 267-279.

36. Alpsoy E, Er H, Durusoy C, Yilmaz E. The use of sucralfate suspension in the treatment of oral and genital ulceration of Behçet disease: a randomized, placebo-controlled, double-blind study. Arch Dermatol 1999; 135: 529-532.

37. Yazici $H$, Pazarli $H$, Barnes CG. A controlled trial of azathioprine in Behçet's syndrome. $\mathrm{N}$ Engl $\mathrm{J}$ Med 1990;322:281-285.

38. Masuda K, Nakajima A, Urayama A, Nakae K, Kogure $\mathrm{M}$, Inaba G: Double-masked trial of cyclosporine versus colchicine and longterm open study of cyclosporin in Behçet's disease. Lancet 1989; 1: 1093-1096.

39. Beilharz MW, Cummins MJ, Bennett AL, Cummins JM. Oromucosal administration of interferon to humans. Pharmaceuticals (Basel) 2010; 3: 323-344.

40. Picciani BLS, Silva-Junior GO, Barbirato DS, Ramos $\mathrm{RT}$, Cantisano $\mathrm{MH}$. Regression of major recurrent aphthous ulcerations using a combination of intralesional corticosteroids and levamisole: a case report. Clinics 2010; 65: 650-652.

41. Chaidemenos $G$, Sidiropoulos $T$, Katsioula $P$, Koussidou-Eremondi T." Colchicine in the management of mucous membrane pemphigoid. Dermatol Ther 2011; 24: 443-445.

42. Khammissa RAG, Ballyram R, Wood NH, Lemmer J, Feller L. Glucocorticosteroids in the treatment of immune mediated oral diseases. South African Dent J 2016; 71: 62-67.

43. Scully C, Flint SR, Bagan JV, Porter SR, Moos KF. Mucosal, cutaneous and mucocutaneous diseases. In: Scully C, Flint SR, Bagan JV, Porter SR, Moos KF, editors. Oral and Maxillofacial Diseases: Informa Healthcare. 2010. 100-132.

44. Oguz A, Uslukaya O, Alabalık U, Turkoglu A, Kapan $\mathrm{M}$, Bozdag Z. Topical $\mathrm{N}$-acetylcysteine improves wound healing comparable to dexpanthenol: an experimental study. Int Surg 2015; 100: 656-661.

45. Proksch E, de Bony R, Trapp S, Boudon S. Topical use of dexpanthenol: a 70th anniversary article. J Dermatolog
Treat 2017; 28: 766-773.

46. Wiederholt $T$, Heise $R$, Skazik $C$, Marquardt $Y$, Joussen S, Erdmann K, Schröder H, Merk HF, Baron JM. Calcium pantothenate modulates gene expression in proliferating human dermal fibroblasts. Exp Dermatol 2009; 18: 969-978.

47. Mandel ID. Antimicrobial mouthrinses: overview and update. J Am Dent Assoc 1994; 125: 2S-10S.

48. Ünür M. Ağız Gargaraları. Diş Hek Derg 2007; 18: 54 59.

49. Karapinar G, Unur M. Current Approaches in Recurrent Aphthous Stomatitis. Clin Experiment Health Sci 2018; 8: 62-66. 